\title{
KERKLEIERSKAP AS BEMIDDELING VAN 'N ONMOONTLIKE WERKLIKHEID: 'N PrAKTIES TEOLOGIESE ONDERSOEK NA DIE ROL VAN LEIERSKAP IN DIE TRANSFORMASIE VAN GEMEENTES
}

Authors:

Frederick (Frikkie) J.

Labuschagne $^{1}$

Malan $\mathrm{Nel}^{1}$

\section{Affiliations:}

${ }^{1}$ Department of Practical

Theology, University of

Pretoria, South Africa

\section{Correspondence to:}

Frikkie Labuschagne

email:

fjmlab@telkomsa.net

Postal address:

Department of Practical Theology, Unversity of Pretoria, Lynwood Road, Hatfield 0083, Pretoria, South Africa

Keywords:

leadership; management of change; complexity; postmodernism; identity of the church; life-cycle approach; strategic planning; relational

\section{Dates:}

Received: 06 May 2010

Accepted: 19 May 2010

Published: 15 Oct. 2010

How to cite this article: Labuschagne, F.J. \& Nel, M., 2010, 'Kerkleierskap as bemiddeling van 'n onmoontlike werklikheid: 'n Prakties teologiese ondersoek na die rol van leierskap in die transformasie van gemeentes', HTS Teologiese Studies/Theological Studies 66(2), Art. \#853, 6 pages. DOI: $10.4102 /$ hts.v66i2.853

This article is available at: http://www.hts.org.za

Note:

This article is a reworked version of a doctoral dissertation in Practical Theology by Dr Frikkie Labuschagne 'Kerkleierskap as bemiddeling van 'n onmoontlike werklikheid: 'n Prakties teologiese ondersoek na die rol van leierskap in die transformasie van gemeentes' that was handed in under the supervion of Prof. Dr Malan Nel at the Department of Practical Theology, University of Pretoria.

\section{ABSTRACT}

Church leadership as mediator for an impossible reality: A practical theological study of the role of leadership in the transformation of congregations

The Church finds herself in a complex society, which currently has a destructive impact on the realisation of the Church. To overcome the challenges of our time, leaders must help to shape new realities creatively and innovatively. Church leadership must find an alternative way of dealing with the issues at stake in order to guide congregations on a challenging journey.

The challenge for congregational leaders is to let the realisation of the Church take place in a revealing and developing manner. The assumption is that the Church is realised organically rather than mechanically and institutionally. Leadership is a dynamic matter that should be realised in a congregational and ecumenical context.

The question to be answered in this article is: What is the role of leaders in a world typified as complex? Because of the complexity of postmodern society, leadership theory and practice have developed beyond the point of planning, organisation and control (acceptable managerial scientific methodology). Leadership in the Church is a collective matter, and, as such, it should be approached and managed holistically with dynamic and relational methods.

\section{INLEIDING}

Die Kerk bevind haarself in 'n tyd van algehele en omvattende verandering. Hiervan het die tradisionele Afrikaanse Kerke met eksklusiewe en behoudende opvattings en benaderings deeglik kennis geneem: 'The turbulent challenges of our time force all institutions and communities to renew and reinvent themselves' (Scharmer 2006:9).

Die toekoms as ' $n$ realiteit op hande ('forthcoming reality') is volgens Pieter de Villiers 'an imminent "now" reality' (2005:11): 'Instead of things to come, things are already here, it is already part of the "now" realities where we live, play and work' (De Villiers 2005:11). Niemandt (2007) vertolk die verbysterende tempo van verandering soos volg:

Die wêreld het verander en niks is meer dieselfde nie: die manier waarop dinge werk, die manier waarop ons daaroor praat, selfs die taal van ons geloof - word meegesleur in die getygolf wat om ons breek.

(Niemandt 2007:11)

Verandering impliseer dat die huidige kontekste uitgedien en onbruikbaar is. Ook Kerkleiers is verantwoordelik om in wese by die daarstel van nuwe oplossings betrokke te raak: nuwe oplossings wat selfs buite die huidige 'norm' en 'vlak van aanvaarbaarheid' gevind moet word. In die proses van doelgerigte leierskap/begeleiding tot vernuwing is strategiese beplanning onmisbaar. Daar blyk ' $n$ sterk korrelasie te wees tussen die lewensvatbaarheid van ' $n$ organisasie, en die wyse waarop sin en relevansie gedefinieer word (kontekstualiteit).

Die Kerk funksioneer egter in 'n groot mate nog in 'n geïnstitusionaliseerde verwysingsraamwerk. Dít het tot gevolg dat waar leierskap plaasvind, dit sterk gelokaliseerd plaasvind en deur institusionele beginsels belyn word. In 'n komplekse samelewing sal leierskap meer dinamies en organies moet geskied. Leierskap mag derhalwe nie tot ' $n$ bepaalde gebied in die Kerk gelokaliseer of beperk word nie. Effektiewe leierskap is in die besonder ' $n$ kollektiewe aangeleentheid.

\section{PROBLEEMSTELLING}

Daar is verskeie faktore (status quo) wat die Nederduitsch Hervormde Kerk van Afrika tans dwing om haarself te herdefinieer en te herorganiseer:

- afname in lidmaatgetalle

- verdwyning van jong lidmate

- beperkte of onvoldoende finansiële bronne

- oënskynlik oneffektiewe en lomp strukture en sisteme waardeur die Kerk bestuur word

- bedankings en erge druk waaronder predikante of kerkrade moet funksioneer

- die relatiewe lewensiklus van gemeentes

- die grootliks geïnstitusionaliseerde aard van die Kerk

- die oorwegend inwaarts gerigte funksionering van die Kerk wat haar eksterne omgewing betref

๑ 2010. The Authors. Licensee: OpenJournals Publishing. This work is licensed under the Creative Commons Attribution License 
- die kommerwekkende versuim by die Kerk om voldoende by veranderende kontekste aan te pas en daarvoor voorsiening te maak

- die voortdurende behoefte dat die Nederduitsch Hervormde Kerk van Afrika haarself ten opsigte van haar roeping in ' $n$ postmoderne samelewing moet verantwoord.

Kerke en gemeentes blyk ' $n$ onvermoë te openbaar om in ' $n$ postmoderne samelewing sinvol en effektief Kerk van die Here te wees. Die uitgangspunt in hierdie artikel is om die handelende geloofsgemeenskap op grond van doelgerigte leierskap en effektiewe gemeentebestuur tot ' $n$ nuwe verhouding met ' $n$ steeds veranderende en transformerende wêreld te begelei.

\section{DIE PLASING (HERORIËNTASIE) VAN DIE KERK IN `N POSTMODERNE SAMELEWING}

\section{Verskillende aksente}

Dit is nie die bedoeling om postmoderniteit te definieer of om die teologie daarteenoor as wetenskap af te baken nie. Inteendeel, met hierdie artikel poog die outeur slegs om hom binne sekere perke of balans van die problematiek en die inhoud van die postmoderniteit te vergewis. Wat gevra word, is eerder ' $n$ teologies verantwoorde beoordeling en benutting van die postmoderniteit.

'n Definisie van postmoderniteit kan voorwaar as ' $\mathrm{n}$ contradictio in terminis beskryf word: 'Diegene wat ' $n$ houvas op die verskynsel wil kry, verstaan dit nie' (Adam 1995:1).

Ströh en Jaatinen (2001) definieer postmodernisme as 'incredulity towards meta-narratives', en bied die volgende verduideliking daarvan:

In simple terms this means that different groups within society take on different perspectives of reality and truth, each trying to make sense of their environment in order to achieve their goals and to make sense of what they perceive and experience.

(Ströh \& Jaatinen 2001:148-165)

Postmodernisme word gekenmerk deur die gelyktydige bestaan van verskillende diskoerse en paradokse, met die uitsondering dat al dié diskoerse en paradokse deel uitmaak van 'n onderlinge komplekse netwerk van verhoudings.

Die paradigmaverskuiwing van die moderne na die postmoderne is ' $\mathrm{n}$ realiteit wat die kerk egter ook verantwoordelik moet interpreteer. Volgens Prins (1997:40) het die moderniteit se soeke na ' $n$ vaste punt, in die postmoderniteit oorgegaan in 'n poging om mense te help verstaan dat daar nie ' $n$ vaste punt is nie, maar eerder ' $n$ pluraliteit van moontlikhede en perspektiewe. ' $\mathrm{n}$ Absolute sekerheid het derhalwe plek gemaak vir beperkte en relatiewe sekerhede soos wat dit in bepaalde kontekste en verhoudings funksioneer.

Volgens Jean Houston (soos aangehaal deur Frost \& Hirsch 2003:182) is ons '...the people of the parenthesis - at the end of one era but not quite at the beginning of the next one. Maps no longer fit the new territories'. Niemandt (2007:50) verduidelik die konteks waarin ontluikende Kerke groei as tye waar die premodernisme sy heel laaste stuiptrekkings gee, die modernisme se hoogbloei verby is en waar die postmoderne tydvak begin. Maar ons woon steeds in drie wêrelde - iets wat ons in Suid-Afrika elke dag ervaar.

Die postmoderne tydvak word aangedui as die era wat die modernisme opvolg en kan daarom as kritiek op die modernisme omskryf word. Die postmodernisme is inderdaad ' $n$ sterk poging om die sin en betekenis wat in die moderne tydvak verlore gegaan het, te herstel.

Die postmoderne denke maak daarop aanspraak dat die waarheid nie subjektief of objektief is nie, maar relasioneel. Die waarheid word in verhoudings, deur gesprek en dialoog heen gevind:

Waarhede word in kommunikasie ontdek, relasioneel, in verhoudinge en in wisselwerking tussen insig, kennis en ervaring van mense met mekaar. Ons het in elk geval altyd te doen met geïnterpreteerde waarheid.

(Pieterse 2002:5)

Vanuit ' $n$ postmoderne paradigma het die teologie die verantwoordelikheid om opnuut oor nuwe of eietydse vraagstukke te besin. Die mate waarin die Kerk antwoorde en oplossings op bogenoemde uitdagings gaan bied, sal haar legitimiteit al dan nie bepaal. Indien die Nederduitsch Hervormde Kerk van Afrika haarself nie ten opsigte van hierdie werklikheid verantwoord nie, sal die rol van die Kerk in die samelewing al hoe meer verduister.

Die verband tussen premodernisme, modernisme en postmodernisme is egter nie opeenvolgend nie, maar gelyklopend. Die Kerk moet in hierdie komplekse tyd kennis neem van premoderne fasette, moderne fasette sowel as postmoderne fasette. Tog kan die Kerk haarself nie van die werklikheid losmaak dat die postmoderne tydsgees die oorwegende tydsgees is waarmee daar in alle fasette van Kerkwees rekening gehou sal moet word nie.

\section{`N ONDERSOEK NA DIE IDENTITEIT VAN DIE KERK}

Die vraag na die identiteit van die Kerk raak haar bestaansdoel. Dit is volgens Nel (1994:21) duidelik dat wanneer ' $n$ Kerk haar bestaansdoel verstaan en formuleer, ' $n$ missie ook geformuleer kan word. Die formulering en daarstel van ' $n$ bestaansdoel behoort daarom alle aktiwiteite in die organisasie van die Kerk vooraf te gaan. Oswald en Kroeger (1988:147) omskryf identiteit as '...that persistent set of beliefs, values, patterns, symbols, stories and style that make a congregation distinctly itself'.

Schippers (1982) beskou die identiteit van die Kerk as ' $n$ meervoudige saak:

Het gaat om een eenheid in veelheid. De veelheid ligt besloten in de existentialen van het gemeente-zijn die tevens anthropologische en culturele existentialen zijn. Daarin staat de gemeente fundamenteel voor de uitdaging van deze eeuw. De eenheid van de veelheid ligt in Jezus Christus, die niet a-maatschappelijk en a-politiek maar in een omvattend herderschap de richting wijst. Daarom heeft de gemeente een saamgestelde identiteit nodig.

(Schippers 1982:191)

Moltmann (1977:1) beskryf die Kerk as 'the people of God', en verduidelik dat ' $[i t]$ will give an account of itself at all times to the God who has called it into being, liberated it and gathered it'. Jesus Christus is die terminus a quo van die Kerk se wese, en 'n poging om haar identiteit te omskryf.

Wanneer die Kerk oor haar wese en bestaansdoel moet besin, bestaan daar egter ' $n$ groot gevaar dat daar eintlik oor die Kerk as instelling en haar vorm besin word. Moltmann (1977) maan soos volg hierteen:

If the church were to ignore its social and political 'Sitz im Leben...' then it would be forsaking the cross of its Lord and would be turning into the illusionary church, occupied merely with itself. (Moltmann 1977:342)

Uit ' $n$ etimologiese perspektief wil dit voorkom of die begrip 'Kerk' meer op die dinamiese 'vergadering' of 'saamwees' van gelowiges rondom die Woord van God fokus. Dit lyk ook of die begrip nie ' $n$ afgebakende en statiese konsep is wat aan spesifieke kenmerke hoef te voldoen nie. Uit ' $n$ BybelsReformatoriese perspektief is dit egter wél duidelik dat die ware Kerk (ecclesia visibilis) sekere kenmerke en eienskappe toon. Tog mag die 'vorm' wat die Kerk aanneem nie in hierdie eienskappe 
en kenmerke opgaan nie. Die 'essensie' moet te alle tye die fokus van die vergadering of samekoms bly.

Leierskap is in wese vormend van aard. Namate leierskap verander en vernuwe, behoort die voorkoms van ' $n$ bepaalde gemeente sowel as die kultuur in daardie gemeente te verander.

\section{Teologiese besinning}

Die Kerk is 'n simbool van God se 'nuwe gemeenskap', en behoort daarom hierdie andersheid te weerspieël. In dié verband meen Weber (1983) soos volg:

What defines its essence is not its 'appearance', however impressive it may be, but God as the One who establishes it in eternity, Jesus Christ as the One who is its 'being'.

(Weber 1983:542)

\section{Dimensies van die Kerk}

Die belydenis 'een, heilige, algemene (katolieke) en apostoliese Kerk': Indien 'n mens 'n dimensie van die Kerk beskryf, beskryf jy by implikasie ' $\mathrm{n}$ dimensie van die Here van die Kerk, Jesus Christus: 'If the church acquires its existence through the activity of Christ, then her characteristics, too, are characteristics of Christ's activity first of all' (Moltmann 1977:338). Die erkenning van die 'een, heilige katolieke en apostoliese Kerk' is 'n erkenning van eenheid met Christus, die heiliging deur die verlossing heen, en die omvattende heerskappy van die Here van die Kerk. Die voorwaarde vir nadenke, erkenning en belydenisse oor die Kerk is die wonder van die geloof.

Hierdie grondliggende waarhede oor die Kerk kom uit die 16de eeu, en kan om dié rede nie van die problematiek van sy tyd losgemaak word nie. Die werklikheidsbeskouing het egter radikaal verander, en dus kan denke met betrekking tot die Kerk ook radikaal verander.

\section{- Die Kerk is een}

Die belydenis 'een Kerk' dien as opdrag: Jesus is die enigste oriëntasiepunt waarin eenheid gehandhaaf en gevind kan word. Die Kerk het nie 'n eenvormige (unis formas) gestalte nie, en

[i]t is not part of the nature of the Church to have a uniform form of worship, nor uniform hierarchies, nor even a uniform theology. In the light of Ephesians 4:4-6, the opposite would seem to be true.

(Küng 1968:275)

Volgens Küng (1968:275) openbaar die Kerk 'n groot mate van diversiteit. Daar is diversiteit in aanbidding: een God, een doop en een nagmaal, maar verskillende volkere, gemeenskappe, tale, rites en vorme van aanbidding. Daar is verskillende gebede, gesange en verskillende vorme van kuns. Daar is diversiteit in teologie: een God, een Here, een hoop en een geloof, maar verskillende teologieë; verskillende sisteme; verskillende vorme van denke; verskillende konsepsuele apparate en terminologieë; verskillende skole, tradisies en navorsingsgebiede; verskillende universiteite en teoloë, maar dan ook verskillende Kerke. Daar is diversiteit in Kerkorde: een God, een Here, een Gees en een liggaam, maar verskillende wyses waarop Kerke georden word; verskillende reëls; verskillende nasies en tradisies; verskillende gewoontes en usansies; verskillende administratiewe stelsels, en daarom ook verskillende Kerke.

- Die Kerk is heilig.

Die teoretiese eenheid van die Kerk staan egter in felle kontras met die empiriese werklikheid wat verdeeld en gefragmenteerd voorkom. Moltmann (1977:) bevestig dat die heilige Kerk 'n her-vormde of her-skeppende Kerk van nuwe kontekste is. In wese is die Kerk dus altyd ecclesia reformata et semper reformanda. Dít kom op die volgende neer:

Through continual new conversion and permanent reformation it testifies to the coming 'reformatio mundi' which is already present in the Spirit - the 'new order of all things' in the kingdom of God, and the sanctification of the whole creation in the glory of God.

(Moltmann 1977:355)
Die Kerk se heiligheid rig haar bedrywighede op die Koninkryk van God. In die proses van dienslewering en deelname in die wêreld word sy ál meer gereinig, gelouter en geheilig. In die opneem van haar eie kruis manifesteer die Kerk die koninkryk van God.

- Die Kerk is katoliek.

Dat die Kerk as katoliek of algemeen beskryf word, hou daarmee verband dat die Kerk altyd op die geheel en die universele gerig is. Die gerigtheid op die universele staan direk in verband met die heilshandelinge van God wat op die universele gerig is. Katolisiteit is volgens Küng (1968:300) 'n kwessie van totaliteit.

Die katolisiteit van die Kerk beskryf nie ' $n$ statiese aspek van haar wese nie, maar fokus eerder op haar dinamiese interaksie met die hele wêreld. Die 'katolieke' Kerk is ' $n$ Kerk met momentum; met ' $n$ sending; gerig op die volledige skepping van God. In haar katolisiteit verteenwoordig die Kerk die eskatologiese 'universele gemeenskap'.

Ware katolisiteit impliseer dus ' $\mathrm{n}$ openheid vir gemeenskap (fellowship) met ander:

The catholic church...does not consist primarily of a global organization and structure of order that embraces all local churches. It finds manifestation in the local churches and through the fellowship with one another.

(Pannenberg 1998:408)

- Die Kerk is apostolies.

Die Kerk se apostoliese karakter kan alleen in die raamwerk van die sending van Christus en die Gees verreken word. Moltmann (1977) en Küng (1968:344) bevestig dat die eenheid, heiligheid en katolisiteit van die Kerk alleen deur haar apostolêre dimensie kan manifesteer. Die apostolêre gerigtheid van die Kerk geskied altyd in ' $\mathrm{n}$ historiese konteks, in die sin dat

[h]istorically the church has its being in carrying out the apostolate. In eternity the church has its being in the fulfilment of the apostolate, that is, in the seeing face to face.

(Moltmann 1977:357)

Die apostoliese gerigtheid van die Kerk is allereers ' $n$ evangeliese gerigtheid - 'n proklamasie en 'n verkondiging dat Jesus Christus die opgestane Here van sy Kerk is - en '[ $t]$ he Reformers therefore demanded that the proclamation of Christ be made the criterion of apostolicity' (Moltmann 1977:359). Die Woord, die Evangelie en die getuienis aangaande Christus is die ware apostolos.

In die vervulling en verwesenliking van haar apostolêre wesenskenmerk getuig die Kerk van 'n nuwe geloofsgemeenskap wat uit mense bestaan wat hulle tot God bekeer:

Eers wanneer jy grensloos kan dink en lewe, deur die 'outsider'as potensiële 'insider 'te sien, gee jy legitimiteit aan die belydenis van die Kerk dat die Kerk 'apostolies' is.

(Van Aarde 2006:107)

Dít verg volgens Van Aarde voorts dat die 'Ander' - ook die straatkind, die prostituut, die anders biologies geskape en anders seksueel georiënteerde, die andersvolkige, die anderskleurige en die anders godsdienstige - nie van toegang tot die Kerk uitgesluit word nie.

\section{LEIERSKAP IN `N TRANSFORMERENDE WÊRELD}

Dit is onmoontlik om te bepaal wat die toekoms vir die Kerk inhou, maar as die tendens en die tempo van transformasie aan die begin van die 21ste eeu enigsins ' $n$ aanduiding is van wat kan volg, sal daar met hierdie kompleksiteit rekening gehou moet word. Wat die veranderlikheid en verandering betref, sal die Kerk haarself voortdurend moet herposisioneer. 
Volgens Callahan (2002) leef ons in ' $\mathrm{n}$ 'megadigm time':

... a megadigm is a time when there is a convergence of multiple paradigm shifts, interacting simultaneously with one another and therefore creating a new age, a markedly new time in the course of human history and human development. It is as though seven dynamic atomic particles of differing shape, size, and energy are interacting with one another. The result is a new creation, a new element, a new substance, a new age.

(Callahan 2002:3)

Dit is noodsaaklik dat leierskap in die Kerk die nuwe dinamiek van kompleksiteit sal verstaan. Om kontekstueel relevant te bly moet leierskap as 'n dinamiese proses verstaan en beoefen word.

In die wêreld van verandering sal leiers baie meer aanpasbaar, kreatief en innoverend moet wees om sinvol leiding te gee, met die gevolg dat

[i]f you are going to learn how to be a good leader, you will have to open your mind to new ideas without discarding all of your old ideas. Moving into the future does not mean letting go of everything you have done in the past. It means getting perpetually smarter about how you integrate the old and the new.

(Beck \& Yeager 2001:3)

\section{Leierskap - 'n omskrywing}

Met betrekking tot ' $n$ definisie van leierskap poog dié artikel nie om die beste geformuleerde definisie weer te gee nie, maar fokus dit eerder op belangrike aksente. 'n Definisie van leierskap sou nie in 'n relasionele wêreld ' $n$ statiese konsep of ontwerp kon wees nie.

Belangrike aksente met betrekking tot leierskap kom in die volgende definisies na vore:

- The 'process' whereby one individual 'influences' others to willingly and enthusiastically direct their efforts and abilities towards attaining defined group or 'organisational goals' (Nel et al. 2001:349).

- $\quad$ Lewis, Goodman en Fandt (1998:435) bied 'n meer tegniese definisie: Leadership involves determining the group's or organization's objectives, motivating, behavior in persuit of these objectives, and influencing group maintenance and culture. But leadership also 'produces change'. It is a 'group phenomenon'; there are no leaders without followers.

- 'n Meer resente definisie is dié van Yukl (2006:8): Leadership is the 'process of influencing' others to 'understand and agree' about what needs to be done and how to do it, and the process of facilitating individual and collective efforts to accomplish 'shared objectives'.

- More than anything else, 'leaders build bridges' that help us move from where we are to where we want to be...someone you 'choose to follow' to a place you wouldn't go by yourself (Barker 1999).

- Leadership in this century means shifting the structure of collective attention at all levels (Scharmer 2006:12).

- Christian leadership is about listening to God and humbly following His lead, doing things that facilitate life transformation, and not worrying about the credit and applause (Barna 2006:139).

Leierskap word hoofsaaklik gedefinieer as 'n 'proses' wat ten doel het om die gesindhede en aksies van individue met betrekking tot ' $n$ spesifieke doel te beïnvloed. Leierskap behels ook die daarstel van 'n nuwe konteks wat mense sal inspireer en motiveer om bepaalde hindernisse of beperkinge te oorkom.

\section{'n Nuwe perspekief tot leierskap}

Die revolusionêre andersheid van die 21ste eeu en 'n steeds veranderende wêreldkonteks is besig om transformasie in organisasies te stimuleer. Hierdie verandering het selfs die Kerk blootgestel en tot in haar wese geraak.

Volgens Roodt (2005:7) het leierskapteorie en -praktyk verby die punt van beplanning, organisasie en beheer (aanvaarbare bestuurswetenskaplike metodiek) ontwikkel. Die gereedskap van 'n ou paradigma is nie meer doeltreffend en effektief in die nuwe bestuursomgewing nie, en

[t]he lessons of living systems provide the best map for this new territory: a mental framework for seeing order in the disorder; powerful distinctions that accelerate change; mental hooks to rely on as we scale the cliffs of the worn-out business model to reach the business model of the future.

(Pascale, Millemann \& Gioja 2000:14)

Die gebrekkige mate waarin Kerke by 'n veranderende omgewing of konteks aanpas, is kommerwekkend. Die afname in lidmaatgetalle en die tempo waarteen gemeentes hul lewensvatbaarheid verloor, spreek vanself. In 'n sekere sin kom die Kerk onbestuurbaar en onaanpasbaar voor. Organisasies is arm aan kultuur, en strukture is wankelrig. Die Kerk as organisasie sal nuut en anders oor haarself en haar rol in 'n postmoderne samelewing moet dink. Nuwe perspektiewe en nuwe metodiek met betrekking tot leierskap sal gegenereer moet word om uiteindelik die 'onmoontlike' te vermag.

\section{Die Kerk as lewende organisme}

Die leier moet elke dag met ' $n$ komplekse en steeds veranderende wêreld, en nie 'n konstante en seker een nie, rekening hou. Slegs wanneer leierskap deur ' $n$ lens kyk wat die Kerk as lewende organisme beskou, word nuwe prosesse ontsluit wat tot effektiewer leierskap en bestuur lei. Die Kerk se bestuursmetafoor kan dus duidelik nie aan 'n masjienperspektief ontleen word nie, maar eerder die perspektief van 'n lewende organisme wat die vermoë openbaar om relasioneel te herorganiseer.

Die meganiese en gedetermineerde filosofie van die Newtoniaanse wetenskap verg orde, stabiliteit en ekwilibrium tussen veranderlikes. So merk Burns (2002) op dat

[i]n a mechanistic Newtonian world, reality is understandable by means of scientific reductionism. Theoretically, the linear universe of Newton can be understood, accurate predictions can be made, and phenomena potentially controlled, as humans apply their reason to break the universe into its most basic parts and then logically put them back together again.

(Burns 2002:42-56)

Volgens Newton (soos aangehaal deur Joubert 1997) is die heelal 'n massiewe klokwerk wat deur 'n Voorsienigheid daargestel is, en tik hierdie klokwerk voort met ' $\mathrm{n}$ beweging waarin elke gebeurtenis 'n verklaarbare oorsaak het (1997:120).

'n Belangrike konsep wat die dinamiese aard van leierskap sinryk omvat, is die lewensiklusproses (Figuur 1). Volgens Roodt (2005:7) is die volgende betekenis in hierdie konsep veranker: ' ... the notion that business organisations are complex living systems that evolve over time as they adapt to a changing environment (context) or, if not, die'.

In die ekologie van lewende sisteme is daar sisteme binne ander sisteme, waar elke afsonderlike sisteem 'n invloed uitoefen op die konteks, maar terselfdertyd ook deur die konteks beïnvloed word. Waar 'n sisteem egter geslote en ontoeganklik is ten opsigte van die konteks waarin hy hom bevind, verloor hy sy lewensvatbaarheid, en kwyn hy weg (die wet van antropie). Vir 'n organisasie om tot uitsonderlike prestasie gelei te word is dit daarom noodsaaklik dat die organisasie, 'as a living system, must be guided and mobilised to adapt continuously and systemically to its environment' (Roodt 2005:7).

Roodt (2005:9) volg 'n holistiese benadering tot leierskap - een waarin leierskap as 'n simbiose tussen strategie, bestuur en leierskap voorgestel word. Hierdie drie funksionele handelinge is oop en het wedersyds betrekking op mekaar as subsisteme in die konteks van die organisasie as lewende sisteem.

Onderliggend aan die perspektief dat organisasies lewende sisteme is wat relasioneel funksioneer, lê verskeie prosesse. 


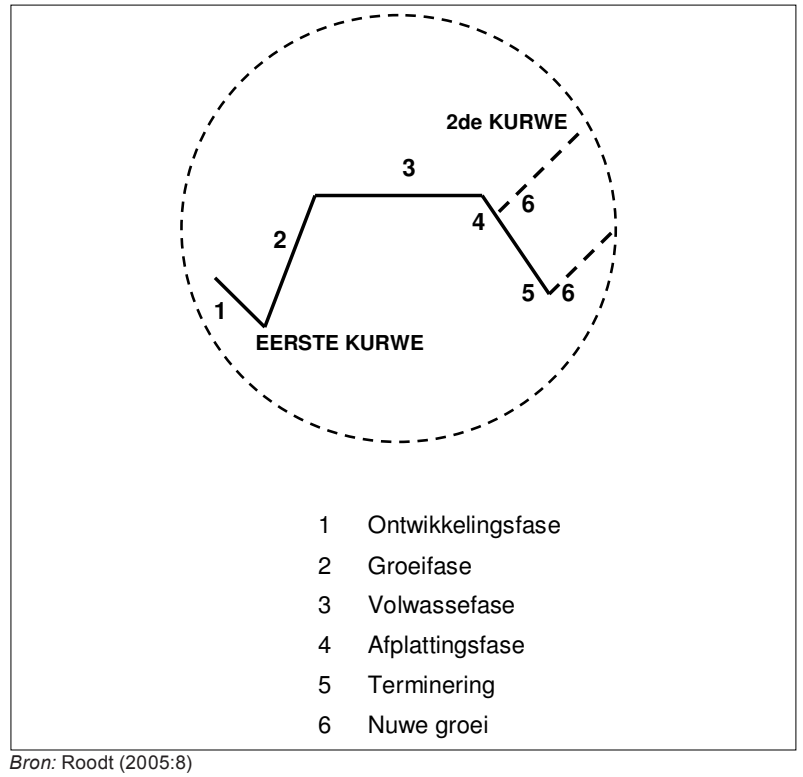

FIGUUR 1

Die lewensiklus van 'n organisasie (die Kerk)

Chaos is ' $n$ kritieke deel van die proses waardeur organisasies voortdurend op hul eksterne omgewing inspeel. In 'n sekere sin vrees elke leier chaos, omdat chaos ' $n$ verlies aan beheer veronderstel. (In die Newtoniaanse wêreld van orde en beheer, is beheer immers ' $n$ noodsaaklike meganisme.) Flower (1993) meen dat

[i]f you think of an organization as a living system then hopefully you can structure it so that it has the capacity for great flexibility and resilience, and the ability to adapt, to change, and to grow.

(Flower 1993:4)

Wat 'n definisie vir die begrip 'chaos' betref, is dit belangrik om tussen die Engelse definisie en die wetenskaplike definisie te onderskei. Die Engelse definisie van chaos beklemtoon ' $n$ toestand of plek van wanorde en verwarring. Die Middelengelse definisie van chaos is ' $n$ kloof of afgrond. Die wetenskaplike definisie van chaos berus egter op die beginsels van fisika en wiskunde, waarvolgens chaos gedefinieer word as die aperiodieke, onvoorspelbare gedrag van veranderlikes in ' $n$ bepaalde sisteem wat sensitief is vir veranderinge vanweë turbulente vloei.

Kompleksiteit verwys daarna dat daar in ' $n$ bepaalde sisteem meer moontlikhede is as wat oënskynlik moontlik is. Volgens Ströh (2005:86) word 'n sisteem as kompleks beskou wanneer die interaksie tussen die verskillende komponente van die sisteem, en die interaksie tussen die een sisteem en ander sisteme, onvoorspelbaar is en dit onmoontlik is om die verskillende komponente te bestudeer. ' $n$ Verdere kritieke kenmerk van komplekse sisteme is die feit dat hul relasionele interaksie voortdurend verander en transformeer, en gevolglik as 'a process of creative destruction, a time for fundamental change, to reorganize, to rearrange' beskryf kan word (Lewin \& Regine 1999:34).

Die Kerk is deel van 'n kontinue, komplekse en transformerende wêreld. Die Kerk as sisteem is nie geïsoleer en onbetrokke nie, en hierdie transformasie geskied nie gedetermineerd en, volgens die Newtoniaanse perspektief, soos die ratte van ' $\mathrm{n}$ masjien nie. Die nuwe komplekse bestuursomgewing funksioneer nie noodwendig op grond van oorsaak-gevolg-gebeure of -gebeurlikhede nie (Wheatley 1999:28):

The machine imagery of the cosmos was translated into organizations as an emphasis on material structure and multiple parts. Responsibilities have been organized into functions. People have been organized into roles.

(Wheatley 1999:29)
Een van die grootste uitdagings vir die Nederduitsch Hervormde Kerk van Afrika in 'n postmoderne samelewing is om diversiteit te erken en in ag te neem, want

[d]iversity provides an opportunity to expand the realm of possibilities while seeking a common ground of understanding, vision, or purpose. With diversity comes a greater expansion of new ideas, methods, and approaches.

(Lewin \& Regine 1999:189)

Die beginsels van kompleksiteitsteorieë stel dit duidelik dat energie en dinamiek in diversiteit opgesluit lê.

\section{DIE BESTUUR VAN VERANDERING}

Die samelewing waarin die Kerk haar bevind, word hoofsaaklik deur diversiteit en pluriformiteit gekenmerk. Verandering is ' $n$ onvermydelike werklikheid, en '[e]mergent approaches to change have a few characteristics in common. Change is seen as a continuous process of learning and experimentation to adapt and align to the turbulent environment' (Ströh \& Jaatinen 2001:148-165).

Die toekoms word as oop beskou, en deur die daarstel van 'n 'organisatoriese visie gee ' $n$ organisasie te kenne dat hy in daardie toekoms wil deel. Die toekoms moet telkens verklaar word en 'sin' moet keer op keer gedefinieer word, want 'the Church is an "open" church. It is open for God, open for men and open for the future of both men and God' (Moltmann 1977:2).

Omgewingsveranderinge dwing die Kerk om kreatief en innoverend te vernuwe. Vanuit die veronderstelling dat alle organisasies as lewende organismes beskou word en derhalwe organies en oop funksioneer, moet leierskap aanvaar dat lewende organismes beperkte lewensiklusse het.

Tweedekurwedenke berus op die beginsel dat leiers toekomsgerig dink en leef. Hierdie toekomsgerigtheid gebeur kreatief en soekend. In 'n konstant veranderende wêreld word oplossings al soekende gevind. Leierskap interpreteer die omgewingsveranderinge, en voor aan die hand van kreatiewe prosesse ' $n$ tweede lewensiklus aan. Leiers moet die gemeente deurlopend motiveer, begelei en oorhaal om toekomsgerig te leef.

So ' $\mathrm{n}$ ontluikende (emergent) benadering ten opsigte van verandering bied egter nie maklike en eendimensionele oplossings nie. In komplekse sisteme word oplossings deur strydende interaksie gegenereer. Volgens Ströh en Jaatinen (2001) is die volgende organisatoriese eienskappe noodsaaklik vir die ontluikende benadering:

... a free flow of information; emphasis on relationship management and symmetrical communication for resolving conflicts; empowerment of people to engage in fitting activity for a quick response to changes; preference for diversity in all roles for a more accurate perception; scenario planning rather than set preplanning; and a participatory approach to guarantee internal interaction, commitment and direction.

(Ströh \& Jaatinen 2001:148-165)

Die Kerk bevind haar in ' $n$ oop en dinamiese wêreld. Indien daar dan aanvaar word dat die Kerk organies funksioneer en derhalwe in gesonde wisselwerking met haar omgewing behoort te staan, behoort die Kerk natuurlik te ontluik en te vernuwe.

\section{Kerkwees - 'n ontluikende benadering}

In die bestuur van verandering is organisasies geneig om ' $n$ kombinasie van ' $n$ berekende en ' $n$ ontluikende benadering te volg:

In a stable environment where small, localised changes are called for, the changes are more planned and focus is placed on technical and structural changes. Emergent approaches are apt in a turbulent environment where changes affect the whole organisation and the focus is thus more on human resources and behaviour.

(Ströh \& Jaatinen 2001:148-165) 
'n Mens kan egter nie konsekwent aanvaar dat die ontluikende benadering die modeloplossing vir Kerkwees in die postmoderne konteks is nie. Vanuit ' $n$ kontekstuele perspektief sou die proses van ontluiking daartoe bydra dat die gemeente se vorm uniek en eiesoortig is, en kan dit inderdaad daartoe lei dat die vorm van die Kerk ál minder tradisioneel sal wees.

Ontluikende Kerke is Kerke wat die impak van die postmodernisme raaksien en dit waag om die Evangelie nuut en kreatief te preek en te leef. Volgens Niemandt (2007:50) soek ontluikende Kerke na die kernwaardes en wese van die heel eerste Christelike gemeentes. In 'n sekere sin vind daar 'n dekonstruksie plaas van wat Niemandt 'Christenheid' noem, en 'n rekonstruksie van die Christelike lewe in 'n nuwe wêreld.

Michael Schrage (soos aangehaal deur Niemandt 2007:51) beskryf die krag van ontluikende Kerke as die krag van die prototipe. Volgens hom moet Kerke in die hoofstroom ontluikende Kerke koester as gawes aan die Kerk, omdat ontluikende Kerke die prototipe van Kerkwees in ' $n$ nuwe wêreld is. Missionale gemeentes is moedige innoveerders wat 'n nuwe era kreatief inlui deur die nodige aanpassings te maak en veranderinge aan te bring. Die geheim van hul aanslag is hul waagmoed (Niemandt 2007:53)

Hierdie artikel het reeds op verskeie plekke daarna verwys dat die Kerk nie meer geïsoleerd en geïnstitusionaliseerd kan wees nie. Kontekstuele bediening begelei die Kerk om effektief te ontluik in die konteks waarin 'n spesifieke gemeente funksioneer.

Dit sou bloot natuurlik wees om gemeentes wat die kenmerke of eienskappe van 'n ontluikende Kerk toon, 'struktureel' of 'organisatories' te groepeer. Indien die Kerk relasioneel ontluik en ' $\mathrm{n}$ bepaalde 'vorm' kry, sou daardie vorm in elke nuwe konteks uniek wees.

\section{SAMEVATTING}

Die Kerk bevind haar in 'n oop en dinamiese wêreld. Op grond van die gewaarwording dat die Kerk organies funksioneer en derhalwe in gesonde wisselwerking met haar omgewing behoort te staan, behoort die Kerk natuurlik te ontluik en te vernuwe. Hierin moet Kerkleiers die handelende geloofsgemeenskap met doelgerigte leierskap en effektiewe gemeentebestuur begelei.

\section{LITERATUURVERWYSINGS}

Adam, A.K.M., 1995, What is postmodern Biblical criticism? [Wat is postmoderne Bybelse kritiek?], Fortress Press, Minneapolis.

Barker, J., 1999, Joel Barker's leadershift: Five lessons for leaders in the 21st century [Joel Barker se leiers verskuiwing. Vyf lesse vir leiers in die 21ste eeu], American Media, Star Thrower, St Paul, Minn, Learning Resources, Cape Town.

Barna, G., 2006, Revolution. Worn-out Church? Finding vibrant faith beyond the walls of the sanctuary ['n Revolusie. Is die kerk uitgeput? Die ontdekking van lewendige geloof buite die mure van die heiligdom], Christian Art Publishers, Vereeniging.

Beck, J.D.W. \& Yeager, N.M., 2001, The leader's window [Deur die oog van die leier gesien], 2nd edn., Davies-Black Publishing, New York.

Burns, J.S., 2002, 'Chaos theory and leadership studies: Exploring uncharted seas [Chaos teorie en leierskap studies: Ontdekkingstog van die onbekende]', Journal of Leadership $\mathcal{E}$ Organizational Studies 9(2), 42-56.

Callahan, K.L., 2002, The future that has come [Die toekoms het gekom], Jossey-Bass, San Francisco.

De Villiers, Pieter, 2005, Face the future [Aanskou die toekoms], Writers Junxion Publishers, Benmore.

Flower, J., 1993, 'The power of chaos: Excerpt from a conversation with Meg Wheatley [Die krag van choas: Uittreksel uit 'n gesprek met Meg Wheatley]', The Healthcare Forum Journal
Frost, M. \& Hirsch, A., 2003, The shaping of the things to come: Innovation and mission for the 21st-century Church [Die vorming van dit wat kom: Innovasie en missie vir die kerk van die 21ste eeu], Hendrickson Publishers, Massachusetts.

Joubert, G., 1997, Die groot gedagte: Abstrakte weefsel van die kosmos, Tafelberg Uitgewers, Kaapstad.

Küng, H., [1968] 1986, The Church [Die kerk], Search Press Limited, Kent.

Lewin, R. \& Birute, R., 1999, The soul at work [Die werkende siel] Simon \& Schuster, New York.

Lewis, P.S., Goodman, S.H. \& Fandt, P.M., 1998, Challenges in the 21st century [Uitdagings in die 21ste eeu], 2nd edn., South-Western College Publishing, Cincinnati, $\mathrm{OH}$.

Moltmann, J., 1977, The Church in the power of the spirit [Die kerk in die krag van die gees], SCM Press, London.

Nel, M., 1994, Gemeentebou, Orion Uitgewers, Halfway House.

Nel, P.S., Gerber, P.D., Van Dyk, P.S., Haasbroek, G.D., Schultz, H.B., Sono, T. \& Werner, A., 2001, Human resources management [Menslike hulpbronne bestuur], 5th edn., Oxford University Press, Cape Town.

Niemandt, N., 2007, Nuwe drome vir nuwe werklikhede: Geloofsgemeenskappe in pas met ' $n$ postmoderne wereld, ABCBoekdrukkers, Epping.

Oswald, R.M. \& Kroeger, O., 1988, Personality type and religious leadership [Peroonlikheidstipe en godsdienstige leierskap], Alban Institute, Washington, DC.

Pannenberg, W., 1998, Systematic theology [Sistematiese teologie], vol. 3, Wm. B. Eerdmans Publishing \& T\&T Clark Edinburgh.

Pascale, R.T., Millemann, M. \& Gioja, L., 2000, Surfing the edge of chaos [Op die rand van chaos], Crown Publishers, New York, NY.

Pieterse, H.J.C., 2002, 'Prediking in 'n postmoderne lewensgevoel', Praktiese Teologie in Suid-Afrika/Practical Theology in South Africa 17(1).

Prins, J.M.G., 1997, 'Post moderniteit en jeugbediening: Enkele aspekte van 'n paradigmaverskuiwing en die implikasies daarvan vir die kerklike jeugbediening', Praktiese Teologie in Suid-Afrika/Practical Theology in South Africa 12(2).

Roodt, A., 2005, 'The soul of leadership [Die siel van leierskap]', Management Today, August 2005, 6-10.

Scharmer, C. Otto, 2006, Theory U: Leading from the future as it emerges. The social technology of presencing [Teorie U: Toekomsleiding soos dit navore kom. Die sosiale tegnologie van teenwoordigheid], The Shambhala Institute for Authentic Leadership.

Schippers, K.A., 1982, 'Werken aan de gewone gemeente II [Werk gaan die gewone gemeente]', Praktische Theologie 9, 181-192.

Ströh, U.M., 2005, An experimental study of organisational change and communication management ['n Eksperimentele studie van organisatoriese verandering en kommunikasie bestuur], University of Pretoria, Pretoria.

Ströh, U., \& Jaatinen, M., 2001, 'Change management and complexity [Bestuur van verandering en kompleksiteit]', Journal of Communication Management 6(2), 148-165.

Van Aarde, A.G., 2006, 'Hoe om in te kom en hoe om binne te bly: Die "groot sendingopdrag" aan die Kerk vandag volgens Matteus 28:16-20', HTS Teologiese Studies/Theological Studies 62(1), 103-122.

Weber, O., 1983, Foundations of dogmatics [Grondslae van dogmatiek], vol. 2, Wm. B. Eerdmans Publishing, Grand Rapids.

Wheatley, Margaret J., 1999, Leadership and the new science: Discovering order in a chaotic world [Leierskap en nuwe wetenskap: Ontdekking van orde in 'n chaotiese wêreld], Berrett-Koehler, San Francisco.

Yukl, Gary A., 2006, Leadership in organizations [Leierskap in organisasies], 6th edn., Pearson Education, Upper Saddle River, NJ. 